\title{
KAJIAN TINGKAT KEBISINGAN DARI AKTIVITAS PELABUHAN
}

\author{
Fahd Ligar Tinimbang \\ Jurusan Teknik Lingkungan, Fakultas Arsitektur Lanskap dan Teknologi Lingkungan, \\ Universitas Trisakti, Jakarta, Indonesia
}

Email Korespondensi : fahd08214021@ std.trisakti.ac.id

\begin{abstract}
ABSTRAK
Indonesia adalah negara maritim. Sebab itu, pelayaran menjadi sektor penting dalam menyokong kehidupan sosial, ekonomi, pemerintahan, pertahanan dan keamanan, budaya, serta lainnya. Untuk mendukung hal tersebut tentunya membutuhkan prasarana berupa pelabuhan. Pelabuhan memiliki beberapa aktivitas yang kompleks, ini menjadikannya sumber pencemaran yang penting terutama ketika pelabuhan dilokalisasi sangat dekat dengan daerah permukiman, karena dalam kesehariannya, pelabuhan juga mempunyai hubungan erat dengan warga sekitar yang mendiami kawasan pelabuhan. Salah satu faktor pencemarnya adalah kebisingan. Maka dari itu pengelolaan dan pengembangan pelabuhan yang tidak tepat dan tidak berkelanjutan berarti dapat mengganggu kualitas hidup warga dan pekerja. Menurut Menteri Tenaga Kerja RI no 13 tahun 2011, Kebisingan adalah semua suara yang tidak dikehendaki yang bersumber dari alat-alat proses produksi dan/atau alat-alat kerja yang pada tingkat tertentu dapat menimbulkan gangguan pendengaran. Karya tulis ilmiah ini bertujuan untuk mengetahui besaran tingkat kebisingan akibat aktivitas pelabuhan serta mengevaluasi kebisingan di area pelabuhan dengan mengacu pada baku mutu KEP48/MENLH/11/1996. Pengukuran tingkat kebisingan pada area pelabuhan dilakukan berdasarkan Keputusan Menteri Lingkungan Hidup Nomor 48 Tahun 1996 Tentang Baku Tingkat Kebisingan. Pengukuran dilakukan dengan mencatat data setiap 5 detik selama 10 menit di beberapa titik. Waktu pengukuran dilakukan selama aktivitas 24 jam pada siang dan malam hari, yaitu tingkat aktivitas paling tinggi selama 16 jam pada selang waktu 06.00-22.00 WIB dan aktivitas malam hari pada selang 22.00-06.00. Melalui karya ilmiah ini diharapkan pencemaran berupa kebisingan dapat direduksi dengan melakukan upaya-upaya pencegahan.
\end{abstract}

Kata Kunci: Kebisingan, Tingkat Kebisingan, Kebisingan Pelabuhan

\section{PENDAHULUAN}

Sistem transportasi mempunyai pengaruh yang besar terhadap perkembangan dan perubahan sistem kegiatan sosial ekonomi suatu kota, sedangkan perubahan sistem sosial ekonomi suatu kota juga akan mempengaruhi sistem transportasi yang ada. Sistem transportasi sendiri berfungsi mengkoordinasikan proses pergerakan manusia dan barang dalam suatu kota dengan mengatur komponen-komponennya (Ferial,2016). Indonesia adalah negara maritim. Satu pulau dengan pulau lainnya terpisah dengan lautan luas. Sebab itu, pelayaran menjadi sektor penting dalam menyokong kehidupan sosial, ekonomi, pemerintahan, pertahanan dan keamanan, budaya, serta lainnya. Pelabuhan adalah sebuah fasilitas di ujung samudera, sungai, atau danau untuk menerima kapal dan memindahkan barang kargo maupun penumpang ke dalamnya. Pelabuhan biasanya memiliki alat-alat yang dirancang khusus untuk memuat dan membongkar muatan kapal-kapal yang berlabuh. Saat ini pelabuhan di seluruh dunia sedang menghadapi hambatan terkait dengan menurunnya kualitas lingkungan, namun pelabuhan juga dituntut untuk terus beroperasi menjalankan aktivitasnya untuk melayani jasa perdagangan dunia yang semakin meningkat. Oleh karena itu, untuk menjaga keberlanjutan proses maritime logistics khususnya jasa kepelabuhanan maka pelabuhan harus mampu beradaptasi dengan perubahan dunia tersebut dengan mengacu pada konsep sustanability port development/greenport (Ahmadi, Dkk, 2015) Pelabuhan memiliki beberapa aktivitas yang kompleks, ini menjadikannya sumber pencemaran yang penting terutama ketika pelabuhan dilokalisasi sangat dekat dengan daerah permukiman, karena dalam kesehariannya, pelabuhan juga mempunyai hubungan erat dengan warga sekitar yang mendiami kawasan pelabuhan. Salah satu faktor pencemarnya adalah kebisingan. Maka dari itu pengelolaan dan pengembangan pelabuhan yang tidak tepat dan tidak berkelanjutan berarti dapat mengganggu kualitas hidup warga dan pekerja. Berdasarkan hal tersebut maka karya tulis ilmiah ini bertujuan untuk mengetahui besaran tingkat kebisingan akibat aktivitas pelabuhan serta mengevaluasi kebisingan di area pelabuhan dengan mengacu pada baku mutu 
KEP-48/MENLH/11/1996 dan mengkaji upaya untuk mengurangi resiko (mitigasi) kebisingan dengan memperhatikan hasil evaluasi kebisingan.

\section{TINJAUAN PUSTAKA}

\section{Pengertian, Macam, dan Dampak Kebisingan}

Menurut Menteri Tenaga Kerja RI no 13 tahun 2011, Kebisingan adalah semua suara yang tidak dikehendaki yang bersumber dari alat-alat proses produksi dan/atau alat-alat kerja yang pada tingkat tertentu dapat menimbulkan gangguan pendengaran, sementara menurut KepMen LH No. 48/11/1996, kebisingan adalah bunyi yang tidak diinginkan dari usaha atau kegiatan dalam tingkat dalam tingkat dan waktu tertentu yang dapat menimbulkan gangguan kesehatan manusia dan kenyamanan lingkungan. Kebisingan dapat juga diartikan sebagai bentuk suara yang tidak sesuai dengan tempat dan waktunya, sehingga secara umum kebisingan dapat diartikan sebagai suara yang merugikan manusia dan lingkungannya.

Menurut Suma'mur, (2009) macam kebisingan dibagi menjadi 4 yaitu :

1. Kebisingan kontinyu dengan spektrum frekuensi yang luas (steady state wide band noise), misalnya : kipas angin, suara katup mesingas, mesin tenun dan lain-lain.

2. Kebisingan kontinyu dengan spektrum frekuensi sempit (steadystate narrow band noise), misalnya : suara sirine, generator, compressor, suara gergaji sirkuler dan lain-lain.

3. Kebisingan terputus-putus (intermittent), misalnya : kebisingan yang terdapat di lapangan udara, di jalan raya dan lain-lain.

4. Kebisingan impulsif berulang, misalnya : mesin tempa diperusahaan

Apabila kebisingan tersebut berlangsung dalam kurun waktu yang cukup lama dan terusmenerus, dapat mengakibatkan gangguan fisiologis dan psikologis pada manusia. Gangguan fisiologis di antaranya adalah bergesernya ambang pendengaran dan dapat mempengaruhi kerja organ-organ tubuh. Sedangkan gangguan psikologis di antaranya adalah sifat lekas marah, sulit tidur (insomnia) dan berkurangnya produktivitas kerja (Wardika, 2012).

Sementara menurut Ernawati (2016), dampak dari kebisingan terhadap kesehatan masyarakat antara lain gangguan komunikasi, gangguan psikologis (gangguan bekerja, belajar, tidur, kejengkelan, kecemasan dan lainnya). Sedangkan keluhan somatik tuli sementara dan tuli permanen merupakan dampak yang dipertimbangkan dari kebisingan di lingkungan kerja atau industri

\section{Sumber Kebisingan di Pelabuhan dan Baku Mutu, dan Pengendalian Kebisingan}

Kebisingan dari daerah pelabuhan, tidak hanya bersumber dari kapal dan operasi perdagangan (mesin kapal, tindakan bongkar muat) tetapi juga dari kegiatan industri dan galangan kapal seperti memperbaiki galangan kapal, kebisingan dari operasi di lambung kapal, serta layanan tambahan yang seperti aktivitas truk container dan truk trailer yang menimbulkan kebisingan, perangkat peringatan suara derek, dan penggunaan pembangkit listrik yang berlokasi di di area pelabuhan. Dengan cara ini, polusi suara dapat menghasilkan efek negatif, baik ke ekosistem alami dan populasi permukiman yang menyebabkan efek negatif dan kerusakan pada kesehatan manusia. (Corrado, 2014).

Menurut Rob Witte (Green Port, 2015), sumber kebisingan dari aktivitas di pelabuhan antara lain

1. Granty Crane : $100-110 \mathrm{~dB}(\mathrm{~A})$

2. 16 tonne fork lift truck : $105-110 \mathrm{~dB}(\mathrm{~A})$

3. Automatic Guided Vehicle : 100 (electrik/hybrid) - 110 (diesel) dB(A)

4. Truk : 102 (berkendara lambat) - 110 (akselerasi) $\mathrm{dB}(\mathrm{A})$ 
Baku tingkat kebisingan yang diperuntukan kawasan/lingkungan kegiatan sesuai dengan Keputusan Menteri Negara Lingkungan No. KEP-48/MENLH/11/1996 adalah sebagai berikut:

Tabel 1 Baku Tingkat Kebisingan

\begin{tabular}{lc} 
Peruntukan Kawasan/ Lingkungan Kegiatan & $\begin{array}{c}\text { Tingkat } \\
\text { Kebisingan } \\
\text { dB(A) }\end{array}$ \\
\hline a. Peruntukan Kawasan & 55 \\
1. Perumahan dan pemukiman & 70 \\
2. Perdagangan dan jasa & 65 \\
3. Perkantoran dan perdagangan & 50 \\
4. Ruang Terbuka Hijau & 70 \\
5. Industri & 60 \\
6. Pemerintahan dan fasilitas umum & 70 \\
7. Rekreasi & \\
8. Khusus: & \\
- Bandar udara *) & \\
- Stasiun Kereta Api *) & 70 \\
- Pelabuhan Laut & 60 \\
- Cagar Budaya & \\
b. Lingkungan Kegiatan & 55 \\
1. Rumah Sakit atau sejenisnya & 55 \\
2. Sekolah atau sejenisnya & 55 \\
3. Tempat ibadah atau sejenisnya &
\end{tabular}

Sumber : Kep. MenLH No. 48 tahun 1996

Kontrol kebisingan dalam suatu lingkungan tergantung pada dua faktor, kondisi atmosfer dan hambatan kebisingan lainnya seperti dinding atau vegetasi (Ramandha, 2019). Hal ini terkait penelitian yang pernah dilakukan sebelumnya tentang bising lalu lintas, disebutkan bahwa hasil pengukuran tingkat kebisingan pada beberapa titik dan volume lalu lintas, terdapat keterkaitan antara volume lalu lintas, tingkat kebisingan dan posisi alat ukur yang terhalang atau tidak terhalang oleh pohon, tembok dan/atau pagar (Kurnia, 2018).

Menurut Ratih (2009), Pengendalian bising secara umum dapat dilakukan dengan 3 cara, antara lain :

1. Pengendalian kebisingan pada sumbernya.

2. Pengendalian bising yang ditransmisikan.

3. Pengendalian bising pada penerima.

\section{METODE DAN ANALISIS}

Pengukuran tingkat kebisingan pada area pelabuhan dilakukan berdasarkan Keputusan Menteri Lingkungan Hidup Nomor 48 Tahun 1996 Tentang Baku Tingkat Kebisingan. Pengukuran dilakukan dengan mencatat data setiap 5 detik selama 10 menit di beberapa titik. Ada beberapa cara untuk menentukan titik sampling, salah satunya adalah dengan observasi langsung untuk menentukan sumber dan area kebisingan. Waktu pengukuran dilakukan selama aktivitas 24 jam pada siang dan malam hari, yaitu tingkat aktivitas paling tinggi selama 16 jam pada selang waktu 06.00-22.00 WIB dan aktivitas malam hari pada selang 22.00-06.00. Setiap pengukuran harus dapat mewakili selang waktu tertentu dengan menetapkan paling sedikit 4 waktu pengukuran pada siang hari dan pada malam hari paling sedikit 3 waktu pengukuran, sebagai contoh :

1. L1 diambil pada jam 07.00 mewakili jam $06.00-09.00$

2. L2 diambil pada jam 10.00 mewakili jam $09.00-11.00$

3. L3 diambil pada jam 15.00 mewakili jam $14.00-17.00$

4. L4 diambil pada jam 20.00 mewakili jam $17.00-22.00$

5. L5 diambil pada jam 23.00 mewakili jam $22.00-24.00$

6. L6 diambil pada jam 01.00 mewakili jam $24.00-03.00$

7. L7 diambil pada jam 04.00 mewakili jam $03.00-06.00$ 


\section{Pengambilan Data dan Alat}

Untuk mengambil data kebisingan digunakan alat Sound Level Meter. Sound Level Meter (SLM) adalah suatu alat yang digunakan untuk mengukur kebisingan, suara yang tak dikehendaki, atau yang dapat menyebabkan rasa sakit ditelinga. Sound level meter biasanya digunakan di lingkungan kerja seperti, industri penerbangan dan sebagainya. Global Positioning System (GPS) untuk menentukan letak di permukaan bumi dengan bantuan penyelarasan (synchronization) sinyal satelit yang mengirimkan sinyal gelombang mikro ke bumi. Sinyal ini diterima oleh alat penerima di permukaan, dan digunakan untuk menentukan letak, kecepatan, arah, dan waktu, Tripod untuk menopang SLM, dan Stopwatch untuk menghitung waktu.

\section{PENUTUP}

Berdasarkan pembahasan mengenai aktivitas pelabuhan dan peran sentral pelabuhan terhadap perekonomian khususnya di Indonesia serta mengetahui dampak kebisingan terhadap manusia dan ekosistem. Penelitian lebih lanjut mengenai kajian tingkat kebisingan di area pelabuhan penting untuk dilakukan

\section{DAFTAR PUSTAKA}

Suma'mur, PK. 2009. Higiene Perusahaan Dan Kesehatan Kerja, Jakarta: Sagung Seto.

Keputusan Menteri Negara Lingkungan Hidup. Kep 48/MENLH/11/1996 tentang Baku Tingkat Kebisingan. Kementerian Lingkungan Hidup, Jakarta, 1996

Peraturan Menteri Tenaga Kerja dan Transmigrasi Nomor Per.13/MeN/X/2011 tentang Nilai Ambang Batas Faktor Fisika dan Faktor Kimia di Tempat Kerja. Kementerian Tenaga Kerja dan Transmigrasi, Jakarta, 2011

Aulia Ramandha, Wisnu Eka Yulyanto, Sandra Madonna. 2019. Studi Tentang Penghalang Kebisingan yang Efektif di Sekolah (SMAN 02) Cibinong. Jakarta. Fakultas Teknik dan Ilmu Komputer, Universitas Bakrie.

DOI : http://dx.doi.org/10.25105/urbanenvirotech.v2i2.4360

Muhammad Kurnia, Muhammad Isya, Muhammad Zaki. 2018. Tingkat Kebisingan Yang Dihasilkan Dari Aktivitas Transportasi (Studi Kasus Pada Sebagian Ruas Jalan : Manek Roo, Sisingamangaraja Dan Gajah Mada Meulaboh). Banda Aceh. Fakultas Teknik Universitas Syiah Kuala.

DOI: 10.24815/jarsp.v1i2.10936

Wardika, I Ketut, I Gusti Putu Suparsa dan D.M. 2012. Analisis Kebisingan Lalu Lintas pada Ruas Jalan Arteri. Denpasar: Fakultas Teknik Universitas Udayana.

Corrado Schenone, Ilaria Pittaluga, Simona Repetto and Davide Borelli. 2014. Noise Pollution Management In Ports. Beijing/China.

R. Witte. Regulation Of Noise From Moored Ships. Green Port. 2015

Ernawati, Melati Ferianita Fachrul, Hernani Yulinawati. 2016. Analisis Pengaruh Tingkat Kebisingan Lalulintas Terhadap Lingkungan Kampus A - Universitas Trisakti A Grogol, Jakarta Barat dan Masyarakat di Sekitarnya. Jakarta. Fakultas Arsitektur Lanskap dan Teknologi Lingkungan Universitas Trisakti

Dwilestari, Ratih. 2009. Pengendalian tingkat kebisingan Di cabin abk (anak buah kapal) kn.p 329 Akibat mesin, ITS Surabaya.

Linardita Ferial, Endro Suswantoro, Mawar DS Silalahi. 2016. Analisis Tingkat Kebsisingan di Terminal Pakupatan Kabupaten Serang, Provinsi Banten. Jakarta. Fakultas Arsitektur Lanskap dan Teknologi Lingkungan Universitas Trisakti.

Nurdin Ahmadi, Tridoyo Kusumastanto, Eddy Ihut Siahaan. 2015. Strategi Pengembangan Pelabuhan Berwawasan Lingkungan (Greenport) Studi Kasus: Pelabuhan CigadingIndonesia Development Strategy Of Greenport Case Study: Cigading Port-Indonesia. Bogor. Insitut Pertanian Bogor. 
